\title{
Induction by 7,12-dimethylbenz( $a$ )anthracene of molecular and biochemical alterations in transformed human mammary epithelial stem cells, and protection by $N$-acetylcysteine
}

\author{
SILVIO DE FLORA ${ }^{1}$, SONIA SCARFi ${ }^{2}$, ALBERTO IZZOTTI ${ }^{1}$, FRANCESCO D'AGOSTINI ${ }^{1}$, \\ CHIA-CHENG CHANG ${ }^{3}$, MARIA BAGNASCO ${ }^{1}$, ANTONIO DE FLORA ${ }^{2}$ and JAMES E. TROSKO ${ }^{3}$ \\ Departments of ${ }^{1}$ Health Sciences, Section of Hygiene and Preventive Medicine and ${ }^{2}$ Experimental Medicine, \\ Section of Biochemistry, and Center of Excellence for Biomedical Research, University of Genoa, \\ I-16132 Genoa, Italy; ${ }^{3}$ National Food Safety Toxicology Center, Department of Pediatrics and \\ Human Development, Michigan State University, East Lansing, MI 48824, USA
}

Received March 9, 2006; Accepted May 2, 2006

\begin{abstract}
Several lines of evidence suggest that stem cells are major targets for carcinogens. A normal human breast epithelial cell type was previously shown to possess stem cell characteristics. Further cell lines were derived following sequential transfection with SV40 large T-antigen (immortal, non-tumorigenic M13SV1 cells), exposure to X-rays (weakly tumorigenic M13SV1R2 cells), and ectopic expression of c-erbB2/neu (highly tumorigenic M13SV1R2N1 cells). We evaluated some characteristics of these cells and their susceptibility to the breast carcinogen 7,12-dimethylbenz( $a$ )anthracene (DMBA). Compared to M13SV1 cells, the two untreated tumorigenic cell lines displayed higher levels of connexin 43 expression and $\mathrm{NF}-\kappa \mathrm{B}$ nuclear translocation, and a higher frequency of fhit loss. The baseline nuclear translocation of AP-1 and
\end{abstract}

Correspondence to: Dr Silvio De Flora, Department of Health Sciences, Section of Hygiene and Preventive Medicine, University of Genoa, via A. Pastore 1, I-16132 Genoa, Italy

E-mail: sdf@unige.it

Abbreviations: AP-1, activator protein-1; Cx, connexin; $\mathrm{Cx} 43$, connexin 43; DMBA, 7,12-dimethylbenz(a)anthracene; DMSO, dimethylsulfoxide; fhit, fragile histidine triad; GJIC, gap junctional intercellular communications; GSH, reduced glutathione; HBECs, human breast epithelial cells; mtDNA, mitochondrial DNA; MTT, 3-(4,5-dimethylthiazolium-2-yl)-2,5-diphenyl-tetrazolium bromide; NAC, $N$-acetyl-L-cysteine; NF-кB, nuclear factor $\kappa \mathrm{B} ; 8-\mathrm{OH}-\mathrm{dG}$, 8-hydroxy-2'-deoxyguanosine; PAH, polycyclic aromatic hydrocarbon; PBS, phosphate-buffered saline; PCR, polymerase chain reaction; pCREB, phosphorylated cAMP responsive elementbinding; TPA, 12-O-tetradecanoylphorbol-13-acetate; TUNEL, terminal deoxy-nucleotidyl transferase mediated dUTP nick-end labeling

Key words: stem cells, 7,12-dimethylbenz( $a$ )anthracene, $N$-acetylcysteine, signal transduction, DNA alterations, apoptosis
pCREB was particularly evident in M13SV1R2N1 cells and was further enhanced by DMBA treatment, indicating an interaction between c-erbB2/neu and DMBA-induced signalling. Treatment with DMBA did neither affect the baseline fhit loss nor p53 mutation, whereas it increased $\mathrm{NF}-\kappa \mathrm{B}$ nuclear translocation, the proportion of apoptotic cells, and the levels of connexin 43, common 4977-bp mitochondrial DNA deletion, and bulky adducts to nuclear DNA. DMBA-treated M13SV1 cells underwent significant oxidative DNA damage and exhibited the highest DNA adduct levels, while they had the lowest apoptotic rate. Co-treatment of cells with $\mathrm{N}$-acetylcysteine (NAC) attenuated DMBA-induced toxicity and DNA alterations, particularly in M13SV1 cells. Thus, the immortal cell line derived from the normal human adult breast stem cell without further tumorigenic progression is the most susceptible both to DMBA-related alterations and to the protective effects of NAC.

\section{Introduction}

One of the oldest hypotheses of the origin of cancers is the stem cell theory (1-7), albeit the de-differentiation hypothesis still has not been ruled out (8). Evidence for the stem cell theory of carcinogenesis includes the common phenotypes of stem cells and tumor cells and the demonstration that stem cells were highly susceptible to neoplastic transformation (9).

Within the last decade, normal adult human multipotential stem cells have been identified and/or isolated (10-20). At least two markers, namely, the non-expression of connexin (Cx) genes and non-functional gap junctional intercellular communications (GJIC) (21) and the expression of the Oct-4 gene (13) have been associated with these various adult human stem cells. In addition, the discovery of 'cancer stem cells' (22-28) has provided evidence that tumor growth is initiated and sustained by tumor stem cells.

The question remains as to the origin of the 'cancer stem cells'. Are they potentially-derived from the normal adult breast stem cell, or rather did embryonic or stem cell-related genes get 're-expressed' during the multi-step, initiation, 
promotion, and progression processes of carcinogenesis (29)? Recently, Ponti et al (28) cultured tumorigenic human breast cancer stem cells as non-adherent mammospheres that shared two of the major characteristics of the normal human breast stem cells and breast tumor cells, namely, the expression of the Oct-4 gene and the non-expression of the Cx43 gene.

Ten years ago, two types of human breast epithelial cells (HBECs) were developed from reduction mammoplasty (11). One of them, referred to as Type I HBECs, shows stem cell characteristics and is more susceptible to telomerase activation and immortalization (9). Evidence that these normal adult cells are stem cells includes the ability to differentiate into other cell types and to form 'budding/ductal organoids' on Matrigel that resemble in vivo breast structures (30), expression of the Oct-4 gene, lack of expression of the Cx43 gene, and the deficiency in GJIC $(11,13)$.

These cells are highly susceptible to telomerase activation and immortalization by the SV40 large T-antigen (9). Hence, a cell line (M13SV1) was derived by transfecting Type I HBECs with a plasmid carrying the SV40 large T-antigen (11). cDNA microarray data indicated that many genes were either up- or down-regulated in M13SV1 cells compared to Type 1 HBECs (31). Both Type 1 HBECs and M13SV1 cells are nontumorigenic (32), lack expression of $C x$ genes, and do not show GJIC $(13,21,30)$. M13SV1 cells were transformed into weakly tumorigenic cells (M13SV1R2) following exposure to X-rays and, further on, into highly tumorigenic cells (M13SV1R2N1) by transducing the c-erbB/neu oncogene (32).

The distinctive origin and characteristics of these Type I HBEC-derived cell lines, and in particular their stem-like nature prompted us to evaluate their susceptibility to treatment with 7,12-dimethylbenz(a)anthracene (DMBA), a polycyclic aromatic hydrocarbon (PAH) that is extensively used in experimental studies as a presumptive prototype mutagen, a signal transduction modulator and a known breast and skin carcinogen. In particular, we evaluated in parallel the cytotoxicity of DMBA in these cells, and assessed a number of properties, including both baseline and DMBA-induced expression of $\mathrm{Cx} 43$, nuclear translocation of the transcription factors $\mathrm{NF}-\kappa \mathrm{B}, \mathrm{AP}-1$, and $\mathrm{pCREB}$ protein, the proportion of apoptotic cells, the effects on the products of the oncosuppressor genes $p 53$ and fhit, the levels of bulky DNA adducts and of oxidative DNA damage, in terms of 8-hydroxy-2'deoxyguanosine (8-OH-dG), and the common 4977-bp mtDNA deletion. Moreover, most of the above end-points, in either untreated or DMBA-treated cells, were investigated by exposing the cells to NAC, a precursor and analogue of Lcysteine and reduced glutathione (GSH) that has been shown to possess a variety of antigenotoxic and anticarcinogenic effects and mechanisms $(33,34)$. Moreover, epidemiological studies showed that higher plasma total cysteine concentrations were significantly associated with a lower risk of breast cancer (35).

The results obtained show differential baseline characteristics and susceptibility to DMBA of the three cell clones investigated, and provide evidence for the ability of NAC to inhibit DMBA-induced toxicity, DNA alterations, and intracellular signal-induced epigenetic events, particularly in the M13SV1 cell clone retaining stem cell properties.

\section{Materials and methods}

Cell cultures. The M13SV1, M13SV1R2, and M13SV1R2N1 cells were obtained as described (32). Cell cultures and media were shipped from the Michigan State University to the University of Genoa. All cell lines were cultured in MSU-1 medium (11) supplemented with 5\% fetal bovine serum at $37^{\circ} \mathrm{C}$ in incubators supplied with $5 \% \mathrm{CO}_{2}$ and humidified air. All experiments, excepting viability, were performed with confluent cells in $175-\mathrm{cm}^{2}$ flasks.

Reagents. DMBA and NAC were purchased from Sigma Chemical Co. (St. Louis, MO). DMBA was dissolved in DMSO and NAC in PBS, pH 7.4.

Cell viability. To assess the cytotoxicity of DMBA on the three cell lines, the 3-(4,5-dimethylthiazolium-2-yl)-2,5diphenyl-tetrazolium bromide (MTT) test was performed as previously described (36). Briefly, each one of the three cell lines was seeded in 96-well plates at 30,000 cells/well. The cells were incubated for $48 \mathrm{~h}$ at $37^{\circ} \mathrm{C}$ in the presence of various concentrations of DMBA $(0.08,0.8,8$, and $80 \mu \mathrm{M})$ in medium containing $0.04 \%$ DMSO, with or without $10 \mathrm{mM} \mathrm{NAC.} \mathrm{Cell}$ medium containing $0.04 \%$ DMSO was used as a negative control. At the end of the treatment, the wells were washed with complete medium, then $1.2 \mathrm{mM}$ MTT in complete medium was added and the incubation was further carried out for $90 \mathrm{~min}$ at $37^{\circ} \mathrm{C}$. Finally, the medium was gently removed from the wells and formazan crystals were solubilized with $200 \mu 1$ of DMSO. The plates were then scored at $570 \mathrm{~nm}$ on a Microplate reader Model 450 (Bio-Rad Laboratories, Hercules, CA).

Connexin 43 and nuclear translocation of transcription factors. M13SV1, M13SV1R2 and M13SV1R2N1 cells, cultured in MSU-1 complete medium, were incubated with $0.8 \mu \mathrm{M}$ DMBA and then stained to analyze, by confocal microscopy, $\mathrm{Cx} 43$ positivity and the nuclear translocation of the transcription factors NF- $\mathrm{B}, \mathrm{AP}-1$, and pCREB protein. The cells were seeded in 4-well Lab-Teck chamber slides (Nalge Nunc Int., Naperville, IL) at 50,000 cells/well. The day after, the cells were incubated with DMBA at $37^{\circ} \mathrm{C}$ for either 6 or $24 \mathrm{~h}$. After incubation, the cells were washed 3 times with PBS, pH 7.4, and fixed for 30 min with $4 \%$ paraformaldehyde in PBS at room temperature. The wells were then washed 5 times with PBS and the cells were permeabilized with $0.05 \%$ Triton X-100 in PBS for $30 \mathrm{~min}$ at room temperature. The cells were again washed 5 times with PBS and stained with the primary antibodies, diluted 1:100 (rabbit anti-Cx43 from Zymed Laboratories Inc., San Francisco, CA; rabbit antiNF- $\kappa$ B, rabbit anti-c-jun, and rabbit anti-p-CREB-1 from Santa Cruz Biotechnology Inc., Santa Cruz, CA), followed by Alexa 488-conjugated specific secondary antibodies diluted 1:500 (Molecular Probes, Invitrogen, Carlsbad, CA). Finally, the nuclei were stained with $10 \mu \mathrm{g} / \mathrm{ml}$ propidium iodide for $10 \mathrm{~min}$ and the cover glasses were mounted by using the Prolong Antifade Kit (Molecular Probes). Images were obtained using a Leica TCS SL confocal microscope equipped with a HCX PL APO CS 63.0x1.40 oil objective. Maximum projections were calculated with Leica LCS software on a 
stack file of 50 sections obtained with a Z-step of $285 \mathrm{~nm}$ and applying an energy laser of $20 \%$.

Apoptosis. The cells were suspended in PBS, $\mathrm{pH} 7.4$, and spun onto slides by means of a cytocentrifuge. The slides were air-dried and fixed in absolute methanol. Apoptosis was evaluated by TUNEL method by using a commercially available kit (TACS XL ${ }^{\mathrm{TM}}$ In situ apoptosis detection kit, Trevigen, Gaithersburg, MD), following the manufacturer's instructions. The slides were scored at a magnification $\mathrm{x} 400$. One thousand cells per cell clone and treatment group were examined. The total number of apoptotic cells was expressed as Apoptosis Labeling Index (\%).

P53 and fhit proteins. P53 protein was detected by immunocytochemistry by using a commercially available kit (P53 protein kit, Novocastra Laboratories Ltd., Newcastle upon Tyne, UK). This kit contains a monoclonal antibody (clone DO-7) that reacts with both wild-type and mutant forms of human p53 protein accumulated in the nucleus. DO-7 recognizes an epitope in the $N$-terminus of p53 protein, known to reside between amino acids $35-49$. The slides were processed according to the manufacturer's instructions, and 1,000 cells were scored at a magnification $\mathrm{x} 400$. The total number of p53-positive cells, reflecting p53 mutation or p53 inactivation, was expressed as Labeling Index (\%).

Fhit protein was detected by immunocytochemistry. A polyclonal rabbit anti-fhit (kindly supplied by Dr N. Zanesi, Columbus, $\mathrm{OH}$ ) was used at a dilution of 1:2,000. The slides were incubated overnight at $4^{\circ} \mathrm{C}$ and then processed with a commercially available immunocytochemistry kit (HistostainPlus Kit, Zymed Laboratories), following the manufacturer's instructions. The slides were scored at magnification $\mathrm{x} 400$. One thousand cells per cell clone and treatment group were examined. The results were expressed in terms of fhit-negative cells $(\%)$.

Bulky adducts to nuclear DNA. DMBA-DNA adducts were analyzed by nuclease $\mathrm{P}_{1}$ enrichment, ${ }^{32} \mathrm{P}$-postlabeling, multidirectional thin layer chromatography and electronic autoradiography, as previously described (37).

Oxidative damage to nuclear DNA. 8-OH-dG was analyzed by trifluoroacetic acid enrichment, ${ }^{32} \mathrm{P}$-postlabeling, bi-directional thin layer chromatography and electronic autoradiography, as previously described (38).

Common 4977-bp mitochondrial DNA deletion. The common 4977-bp mtDNA deletion was analyzed by quantitative realtime PCR according to Hamblet and Castora (39). Two independent $\mathrm{qPCR}$ reactions for each sample were performed to quantify total and deleted mtDNA, respectively.

Total mtDNA quantification was performed using two primers (sense: 5'-CCATCTTTGCAGGCACACTCATC-3'; antisense: 5'-ATCCACCTCAACTGCCTGCTATG-3') flanking a sequence of mtDNA known to be unsusceptible to common deletion and an ad hoc designed fluorescent FAM-labeled and BHQ1-quenched molecular beacon (5'-CGCGATCTCACGC AAGCAACCGCATCCATGATCGCG-3') designed by the software Beacon Designer 4.0 (Premier Biosoft International,
Table I. Evaluation of cytotoxicity, by MTT test, in cell clones derived from human mammary epithelial stem cells treated for $48 \mathrm{~h}$ with varying DMBA concentrations, either in the absence or in the presence of $10 \mathrm{mM}$ NAC.

\begin{tabular}{lcccc}
\hline & & \multicolumn{4}{c}{ Survival of cells $(\%)$} \\
\cline { 3 - 5 } $\begin{array}{l}\text { DMBA } \\
(\mu \mathrm{M})\end{array}$ & $\begin{array}{c}\text { NAC } \\
(10 \mathrm{mM})\end{array}$ & M13SV1 & M13SV1R2 & M13SV1R2N1 \\
\hline \multirow{2}{*}{0.00} & - & $100.0 \pm 5.12$ & $100.0 \pm 1.60$ & $100.0 \pm 2.83$ \\
& + & $100.0 \pm 1.83$ & $100.0 \pm 3.43$ & $100.0 \pm 3.01$ \\
0.08 & - & $82.0 \pm 5.08^{\mathrm{a}}$ & $89.3 \pm 3.61^{\mathrm{a}}$ & $83.4 \pm 4.45^{\mathrm{a}}$ \\
& + & $104.4 \pm 6.61^{\mathrm{d}}$ & $92.3 \pm 21.07$ & $97.4 \pm 3.21^{\mathrm{d}}$ \\
0.80 & - & $76.7 \pm 4.53^{\mathrm{a}}$ & $82.7 \pm 2.63^{\mathrm{a}}$ & $80.0 \pm 6.34^{\mathrm{a}}$ \\
& + & $101.7 \pm 1.22^{\mathrm{d}}$ & $101.0 \pm 2.14^{\mathrm{d}}$ & $103.5 \pm 4.52^{\mathrm{b}, \mathrm{d}}$ \\
8.00 & - & $63.4 \pm 4.78^{\mathrm{a}}$ & $62.1 \pm 4.12^{\mathrm{a}}$ & $64.3 \pm 4.13^{\mathrm{a}}$ \\
& + & $70.0 \pm 2.29^{\mathrm{b}, \mathrm{c}}$ & $67.8 \pm 2.92^{\mathrm{b}, \mathrm{c}}$ & $69.4 \pm 2.82^{\mathrm{b}, \mathrm{c}}$ \\
80.00 & - & $2.2 \pm 1.30^{\mathrm{a}}$ & $2.4 \pm 0.45^{\mathrm{a}}$ & $1.2 \pm 0.12^{\mathrm{a}}$ \\
& + & $10.2 \pm 1.03^{\mathrm{b}, \mathrm{d}}$ & $8.8 \pm 0.93^{\mathrm{b}, \mathrm{d}}$ & $4.0 \pm 0.23^{\mathrm{b}, \mathrm{d}}$ \\
\hline
\end{tabular}

The results are expressed as percentage of the absorbance measured without DMBA, either in the absence or in the presence of NAC. The corresponding SD values were calculated by making a proportion with the SD and mean values of the absorbance yielded by 8 replicate cultures. ${ }^{a} \mathrm{P}<0.001$, significantly decreased as compared with NAC-free controls. ${ }^{b} \mathrm{P}<0.001$, significantly decreased as compared with NAC controls. ${ }^{c} \mathrm{P}<0.01$ and ${ }^{\mathrm{d}} \mathrm{P}<0.001$, significantly higher as compared with the same DBMA dose, in the absence of NAC.

Palo Alto, CA). Deleted mtDNA quantification was performed using two primers (sense 5'-GGCCCGTATTTACCCTA TAG-3'; antisense: 5'-GGTGAGAAGAATTATTCGAGTG-3') flanking the region susceptible to deletion and a specific FAM-labeled molecular beacon (5'-CGCGATCCAGCCTAG CATTAGCAGGAATACCTTGATCGCG-3').

The PCR reaction mixture included $5 \mu 1$ 10X PCR buffer, $0.4 \mu 1100 \mathrm{mM}$ dNTP mix, $2 \mu 150 \mathrm{mM} \mathrm{MgCl}_{2}, 0.5 \mu \mathrm{l}$ Platinum Taq polymerase (Invitrogen), $37.1 \mu 1$ sterile water, $1 \mu 1$ sense primer $(10 \mathrm{mM}), 1 \mu 1$ antisense primer $(10 \mathrm{mM})$, $2 \mu 1$ molecular beacon $(10 \mu \mathrm{M})$, and $1 \mu 1$ DNA $(0.1-1 \mu \mathrm{g})$. Time-temperature ramp was $94^{\circ} \mathrm{C}$ for $2 \mathrm{~min}, 45$ cycles at $94^{\circ} \mathrm{C}$ for $30 \mathrm{sec}$, annealing temperature $\left(54^{\circ} \mathrm{C}\right.$ and $51^{\circ} \mathrm{C}$ for total and deleted mtDNA, respectively) for $30 \mathrm{sec}$, and $72^{\circ} \mathrm{C}$ for $30 \mathrm{sec}$. The reactions were performed in a rotating thermocycler (Rotorgene 3000, Corbett Research, Mortlake, NSW, Australia). FAM emission was acquired at the end of each annealing step. Each sample was tested in 4 independent experiments.

Statistical analyses. The significance of the differences between cell lines and treatment groups was assessed by $\chi^{2}$ analysis for the data, expressed in terms of frequency (apoptotic cells, mutated or inactivated p53 protein, and loss of fhit protein), and by Student's t-test for unpaired data expressed in terms of means \pm SD (cell viability, bulky DNA adducts and oxidative damage to nuclear DNA, and common 4977-bp mtDNA deletion). 


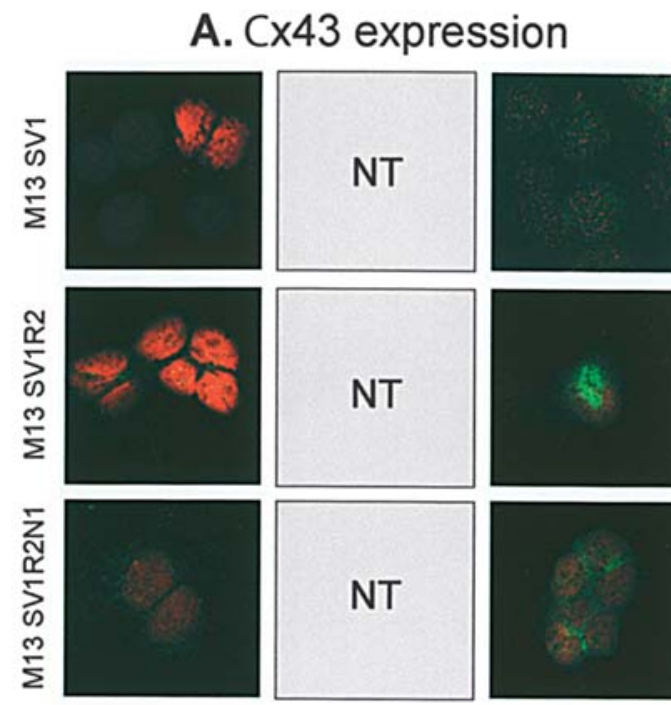

\section{B. NFKB nuclear translocation}
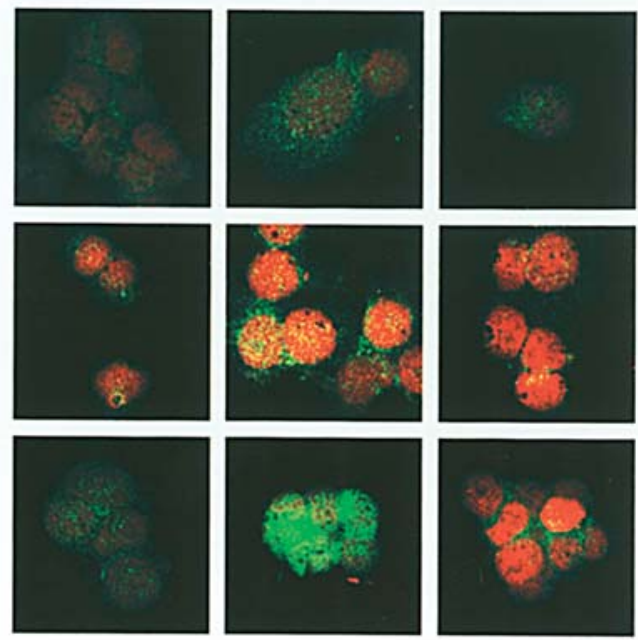
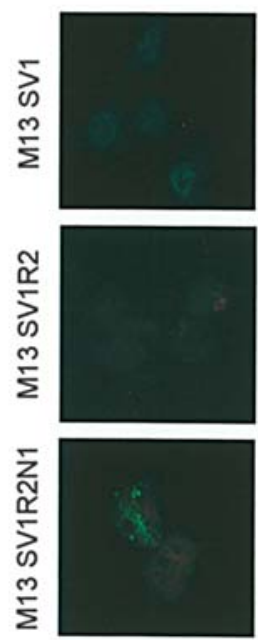

CONTROLS
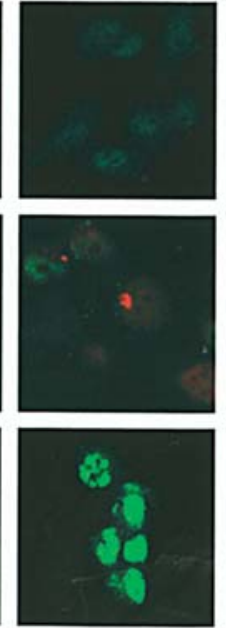

DMBA $(6 \mathrm{~h})$
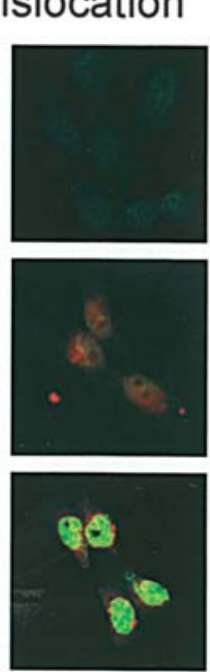

$\operatorname{DMBA}(24 \mathrm{~h})$

\section{D. pCREB nuclear translocation}
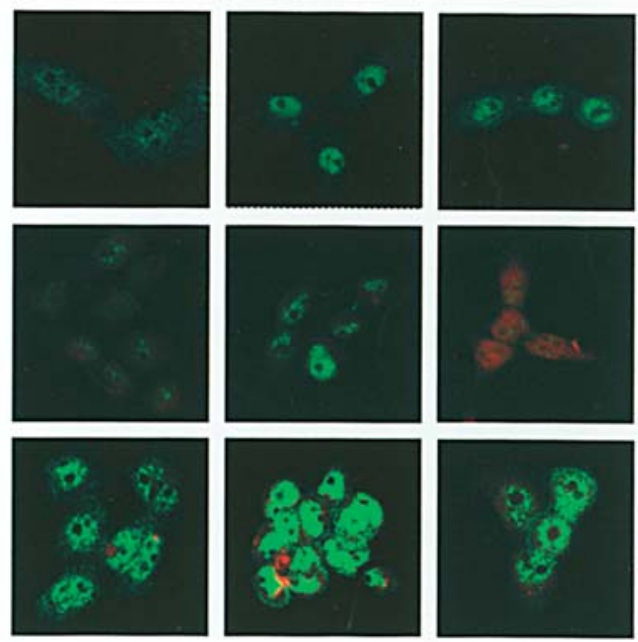

CONTROLS DMBA $(6 \mathrm{~h}) \quad$ DMBA $(24 \mathrm{~h})$

Figure 1. Examples of Cx43 expression and nuclear translocation of the NF-кB, AP-1 and pCREB transcription factors, as assessed by confocal microscopy in three cell clones derived from human mammary epithelial stem cells, either untreated or treated with $0.8 \mu$ M DMBA for 6 or 24 h. Propidium iodide DNA staining is detectable as a red fluorescence of nuclei, and green fluorescence in either cytoplasm and/or nuclei indicates the localization of the transcription factors. NT, not tested.

\section{Results}

Cell viability. The results of cell viability experiments, using the MTT test, are shown in Table I. In the absence of NAC, DMBA induced a significant and dose-dependent loss of cell viability. Almost the totality of cells died at the highest DMBA dose tested $(80 \mu \mathrm{M})$. Toxicity of DMBA was similar in the three cell lines. Irrespective of the cell line, co-treatment with $10 \mathrm{mM}$ NAC significantly attenuated the toxic effects produced by DMBA, at all doses tested. Protection by NAC was complete at 0.08 and $0.8 \mu \mathrm{M}$ DMBA.

Cx43 expression. Examples of results of confocal microscopy analyses regarding Cx43 expression in controls and in 24-h DMBA-treated cells are shown in Fig. 1A. M13SV1 cells did not display any $\mathrm{Cx} 43$ expression in control samples, whereas a light-green dotted positivity was observed after $24 \mathrm{~h}$ of DMBA treatment. In contrast, both M13SV1R2 and M13SV1R2N1 cells were weakly Cx43-positive in control cells, and positivity was remarkably enhanced following DMBA treatment.

Nuclear translocation of transcription factors. The nuclear translocation of the NF- $\mathrm{BB}, \mathrm{AP}-1$ and pCREB transcription factors was monitored in control cells and in cells treated with DMBA for either 6 or 24 h. Examples are shown in Fig. 1, where propidium iodide DNA staining is detectable as a red fluorescence of nuclei, and green fluorescence in either cytoplasm and/or nuclei indicates the localization of the investigated transcription factors.

As shown in Fig. 1B, NF- $\mathrm{B}$ was detectable only in the cytoplasm of untreated cells of all three clones, whereas in M13SV1 cells a nuclear localization became apparent in cells treated with DMBA for either 6 or $24 \mathrm{~h}$. In M13SV1R2N1 cells, the nuclear translocation of $\mathrm{NF}-\kappa \mathrm{B}$ was only evident 
Table II. Evaluation of apoptosis by TUNEL method and of tumor suppressor gene proteins (p53 or fhit) by immunocytochemistry in cell clones derived from human mammary epithelial stem cells, either treated with DMSO (controls) or treated for $48 \mathrm{~h}$ with either $0.8 \mu \mathrm{M}$ DBMA and/or $10 \mathrm{mM}$ NAC.

\begin{tabular}{|c|c|c|c|c|}
\hline \multirow[b]{2}{*}{ End-point } & \multirow[b]{2}{*}{ Treatment of cells } & \multicolumn{3}{|c|}{ Cell clone } \\
\hline & & M13SV1 & M13SV1R2 & M13SV1R2N1 \\
\hline \multirow[t]{4}{*}{ Apoptotic cells (\%) } & Controls & 2.1 & 1.8 & 2.3 \\
\hline & NAC & 3.0 & 2.2 & 1.4 \\
\hline & DMBA & $6.9^{\mathrm{a}}$ & $9.8^{\mathrm{a}, \mathrm{d}}$ & $9.3^{\mathrm{a}, \mathrm{b}}$ \\
\hline & $\mathrm{DMBA}+\mathrm{NAC}$ & $5.2^{\mathrm{a}}$ & $8.1^{\mathrm{a}, \mathrm{d}}$ & $9.4^{\mathrm{a}, \mathrm{d}}$ \\
\hline \multirow{4}{*}{$\begin{array}{l}\text { Mutated or inactivated } \\
\text { p53 protein }(\%)\end{array}$} & Controls & 0.0 & 0.0 & 0.0 \\
\hline & NAC & 0.0 & 0.0 & 0.8 \\
\hline & DMBA & 0.0 & 1.2 & 0.9 \\
\hline & $\mathrm{DMBA}+\mathrm{NAC}$ & 0.0 & 0.0 & 0.0 \\
\hline \multirow{4}{*}{$\begin{array}{l}\text { Loss of fhit } \\
\text { protein }(\%)\end{array}$} & Controls & 2.2 & $5.2^{\mathrm{d}}$ & $4.6^{c}$ \\
\hline & NAC & 1.6 & $6.2^{\mathrm{d}}$ & $5.8^{\mathrm{d}}$ \\
\hline & DMBA & 2.4 & $4.8^{b}$ & $6.0^{\mathrm{d}}$ \\
\hline & $\mathrm{DMBA}+\mathrm{NAC}$ & 3.6 & $5.4^{\mathrm{b}}$ & $5.6^{\mathrm{b}}$ \\
\hline
\end{tabular}

${ }^{\mathrm{a}} \mathrm{P}<0.001$, significantly increased as compared with controls within the same cell line. ${ }^{\mathrm{b}} \mathrm{P}<0.05,{ }^{\mathrm{c}} \mathrm{P}<0.01$, and ${ }^{\mathrm{d}} \mathrm{P}<0.001$, significantly increased as compared with the same treatment in M13SV1 cells.

after $6 \mathrm{~h}$ of DMBA treatment. A similar trend was observed in M13SV1R2 cells, where both background and DMBAinduced NF- $\mathrm{KB}$ levels were higher.

AP-1 staining (Fig. 1C) was barely detectable in untreated M13SV1 and M13SV1R2 cells, whereas a slight positivity was seen in M13SV1R2N1 cells. The effect of DMBA on AP-1 levels was modest in the first two cell lines, while a sharp nuclear AP-1 enrichment was observed in DMBA-treated M13SV1R2N1 cells at both treatment times.

Likewise, pCREB nuclear levels, reflecting the phosphorylated species of this transcription factor, were high in untreated M13SV1R2N1 cells and low in the controls of the first two cell lines. Treatment with DMBA produced extensive nuclear pCREB translocation in all three cell lines, which was particularly remarkable in M13SV1R2N1 cells at $6 \mathrm{~h}$.

Apoptosis. The results relative to detection of apoptotic cells by TUNEL method are summarized in Table II. In the absence of treatments, the number of apoptotic cells was similar in the three cell clones. Exposure of cells to NAC alone did not affect apoptosis, irrespective of the cell line. DMBA treatment of cells caused a statistically significant enhancement of cell apoptosis versus untreated cells (3.3-fold in M13SV1, 5.4-fold in M13SV1R2, and 4.0-fold in M13SV1R2N1). Co-treatment of cells with NAC did not significantly affect the frequency of DMBA-induced apoptosis in any cell line. The proportion of apoptotic cells in DMBA-treated cultures and in NAC-cotreated cultures was significantly lower in M13SV1 than in either M13SV1R2 or M13SV1R2N1.

P53 and fhit gene proteins. As shown in Table II, the frequency of cells positive for mutated or inactivated p53 protein, as detectable by immunocytochemistry using the DO-7 monoclonal antibody, was null or very low, irrespective of the cell line or treatment. Independently of treatments, the loss of fhit protein was significantly more frequent in the two tumorigenic cell lines (M13SV1R2 and M13SV1R2N1), as compared with the parental non-tumorigenic, immortalized cells (M13SV1).

Bulky adducts to nuclear DNA. ${ }^{32} \mathrm{P}$-postlabeling did not detect any appreciable signal in either controls or NAC-treated cells. Conversely, the appearance of intense radioactive spots was detected in DMBA-treated cells. Their pattern of distribution showed the presence of a low-migrating major adduct, present in all DMBA-treated samples, and of four minor adducts, clearly detectable only in DMBA-treated cells without NAC co-treatment. The chromatographic migration rate of these DMBA-DNA adducts was similar to those previously detected in vivo in rat liver and mammary epithelial cells (37).

As shown in Table III, DMBA-induced DNA adducts were 1.8-fold and 1.7-fold higher in M13SV1 cells than in M13SV1R2 and M13SV1R2N1 cells, respectively. No difference was observed between M13SV1R2 and M13SV1R2N1 cells. NAC significantly decreased DMBA-induced DNA adduct formation in all cell lines. This protective effect was more evident in M13SV1 (2.9-fold) than in either M13SV1R2 (1.4-fold) or M13SV1R2N1 (1.6-fold).

Oxidative damage to nuclear DNA. Basal 8-OH-dG levels were similar in the three cell lines, irrespective of treatment with NAC. DMBA induced a slight but significant increase (1.7-fold) only in M13SV1 cells. This effect was prevented by NAC co-treatment (Table III). 
Table III. Bulky DNA adducts and oxidative damage to nuclear DNA (8-OH-dG), and common 4977-bp mtDNA deletion in cell clones derived from human mammary epithelial stem cells, either treated with DMSO (controls) or treated for $48 \mathrm{~h}$ with either $0.8 \mu \mathrm{M}$ DBMA and/or $10 \mathrm{mM}$ NAC.

\begin{tabular}{|c|c|c|c|c|}
\hline \multirow[b]{2}{*}{ End-point } & \multirow[b]{2}{*}{ Treatment of cells } & \multicolumn{3}{|c|}{ Cell clone } \\
\hline & & M13SV1 & M13SV1R2 & M13SV1R2N1 \\
\hline \multirow{4}{*}{$\begin{array}{l}\text { Bulky DNA adducts/ } \\
10^{8} \text { nucleotides }\end{array}$} & Controls & $0.6 \pm 0.15$ & $0.6 \pm 0.11$ & $0.9 \pm 0.20$ \\
\hline & NAC & $0.8 \pm 0.17$ & $0.6 \pm 0.24$ & $0.8 \pm 0.17$ \\
\hline & DMBA & $4.9 \pm 0.28^{\mathrm{c}}$ & $2.8 \pm 0.13^{\mathrm{c}, \mathrm{h}}$ & $2.9 \pm 0.16^{\mathrm{chh}}$ \\
\hline & $\mathrm{DMBA}+\mathrm{NAC}$ & $1.7 \pm 0.23^{\mathrm{c}, \mathrm{f}}$ & $2.0 \pm 0.24^{\mathrm{c}, \mathrm{e}}$ & $1.8 \pm 0.21^{\mathrm{a}, \mathrm{f}}$ \\
\hline \multirow{4}{*}{$\begin{array}{l}8-\mathrm{OH}-\mathrm{dG} / \\
10^{5} \text { nucleotides }\end{array}$} & Controls & $0.3 \pm 0.05$ & $0.3 \pm 0.07$ & $0.2 \pm 0.08$ \\
\hline & NAC & $0.4 \pm 0.08$ & $0.4 \pm 0.20$ & $0.3 \pm 0.07$ \\
\hline & DMBA & $0.5 \pm 0.15^{\mathrm{a}}$ & $0.3 \pm 0.05^{\mathrm{g}}$ & $0.2 \pm 0.06^{\mathrm{g}}$ \\
\hline & $\mathrm{DMBA}+\mathrm{NAC}$ & $0.3 \pm 0.12^{\mathrm{d}}$ & $0.2 \pm 0.10$ & $0.2 \pm 0.09$ \\
\hline \multirow{4}{*}{$\begin{array}{l}\text { Common } 4977-b p \\
\text { mtDNA deletion } \\
\text { (\% of total mtDNA) }\end{array}$} & Controls & $1.3 \pm 0.18$ & $0.9 \pm 0.06$ & $0.9 \pm 0.18$ \\
\hline & NAC & $1.0 \pm 0.19$ & $0.9 \pm 0.16$ & $1.1 \pm 0.15$ \\
\hline & DMBA & $2.1 \pm 0.24^{\mathrm{b}}$ & $1.9 \pm 0.09^{c}$ & $2.0 \pm 0.24^{c}$ \\
\hline & $\mathrm{DMBA}+\mathrm{NAC}$ & $1.9 \pm 0.29^{\mathrm{a}}$ & $1.7 \pm 0.37^{b}$ & $1.8 \pm 0.13^{\mathrm{c}}$ \\
\hline
\end{tabular}

The results are means \pm SD of the results obtained by testing DNA samples in duplicate and in two separate experiments. ${ }^{\mathrm{a}} \mathrm{P}<0.05$, ${ }^{\mathrm{b}} \mathrm{P}<0.01$ and ${ }^{\mathrm{c}} \mathrm{P}<0.001$, significantly increased as compared with controls. ${ }^{\mathrm{d}} \mathrm{P}<0.05,{ }^{\mathrm{e}} \mathrm{P}<0.01$ and ${ }^{\mathrm{f}} \mathrm{P}<0.001$, significantly decreased as compared with DMBA-treated cells. ${ }^{\mathrm{P}}<0.05$ and ${ }^{\mathrm{h}} \mathrm{P}<0.01$, significantly lower as compared with $\mathrm{M} 13 \mathrm{SV} 1$ cells.

Common 4977-bp mitochondrial DNA deletion. No significant difference in the amount of the 4977-bp mtDNA deletion was observed among the three tested cell lines, either untreated or following treatment with NAC alone. The highest basal levels of deletion were detected in M13SV1 cells (1.4-fold higher than either M13SV1R2 or M13SV1R2N1 cells), but this difference was not statistically significant. DMBA significantly increased the deletion in all three cell lines (1.6-, 2.1-, and 2.2-fold in M13SV1, M13SV1R2, and M13SV1R2N1 cells, respectively). In the presence of NAC, the levels of the 4977-bp mtDNA deletion were lower in all three cell lines, but not to a significant extent, and were still significantly higher than in control cells (1.5-, 1.9-, and 2.0-fold in M13SV1, M13SV1R2, and M13SV1R2N1 cells, respectively) (Table III).

\section{Discussion}

The results of the present study provide evidence for the distinctive baseline characteristics of the three cell lines derived from an HBEC with stem cell characteristics and transformed at different stages, and for their differential susceptibility to treatment with DMBA as well. Moreover, the results demonstrate the ability of NAC to inhibit DMBAinduced DNA alterations in these cells.

Compared to non-tumorigenic M13SV1 cells, the weakly tumorigenic M13SV1R2 cells displayed higher basal levels of $\mathrm{NF}-\kappa \mathrm{B}$ nuclear translocation and of $\mathrm{Cx} 43$ expression. Both observations suggest the occurrence of some epigenetic modification of these cells during the neoplastic transformation process. The highly tumorigenic cell line expressing c-erbB2/ neu oncogene (M13SV1R2N1) still maintained an elevated
Cx43 basal expression, although no GJIC has been detected in previous studies (11). However, while the nuclear translocation of NF-кB was barely detectable, this cell line acquired a more pronounced ability to 'spontaneously' translocate AP-1 and, even more strikingly, pCREB into the nucleus. All three transcription factors studied have been shown to activate both pro-inflammatory and anti-apoptotic pathways and in particular several studies describe their fundamental role in the progression of malignancy in breast epithelial cells (40-43).

DMBA enhanced the levels of $\mathrm{Cx} 43$ in all three cell lines. The enhanced expression of the $C x 43$ gene might indicate that some oxidative stress-triggered intracellular signalling induced by DMBA caused this epigenetic change in the immortalized cell line derived from the normal breast stem cell whose Cx43 gene is transcriptionally suppressed (44). Moreover, the nuclear translocation of both AP-1 and pCREB was further enhanced after DMBA treatment. Since this effect is unique with M13SV1R2N1 cells and the major difference between M13SV1R2 and M13SV1R2N1 is the transfection and expression of c-erb2/neu oncogene, this finding suggests a common effect and/or interaction between the c-erb2/neu gene product (p185 c-erb2/neu EGF receptor-like) and DMBAinduced epigenetic signalling. The DMBA-promoted nuclear translocation of $\mathrm{NF}-\kappa \mathrm{B}, \mathrm{AP}-1$, and $\mathrm{pCREB}$ was an early effect, since generally stimulation was more evident after $6 \mathrm{~h}$ rather than after $24 \mathrm{~h}$ of DMBA treatment. Accordingly, this effect seems to involve induction of an oxidative stresstriggered intracellular signalling that affects post-translational modification of these proteins, rather than independent genotoxic alterations leading to rare mutations in the activity of 
these genes. This kind of rapid transcription factor response is associated with tumor promoters such as phorbol esters (45). A number of reports have indicated that DMBA can trigger oxidative stress, in a manner similar to the tumor promoter TPA (46-49). In addition, DMBA has been shown to inhibit, transiently, gap junction function in a manner similar to TPA (50). Stimulation of translocation of both AP-1 and pCREB was more evident in M13SV1R2N1 cells than in either M13SV1 or M13SV1R2 cells, which were conversely more susceptible to the DMBA-related translocation of NF- $\kappa B$. It is noteworthy that the oncogene neu has been related to translocation of AP-1 and CREB in breast cancer cells $(51,52)$.

The two tumorigenic cell lines, M13SV1R2 and M13SV1R2N1, irrespective of c-erbB2/neu incorporation, exhibited a higher frequency of fhit protein loss. The mechanisms underlying the molecular change from M13SV1 to M13SV1R2 cells induced by X-rays, resulting in weakly tumorigenic phenotype, are not known. The higher frequency of fhit loss and the expression of $\mathrm{Cx} 43$ are few of the alterations identified so far. It should be noted that human chromosome 3, where fhit is located, is frequently involved in loss of heterozygosity in breast cancer (53). Thus, the fhit gene seems to be sensitive to ionizing radiation, although fhit $^{-1-}$ cells derived from gene knockout mice are radioresistant due to over-activity of check-points regulated by the ATR/CHK1 pathway (54).

Although the large T-antigen of SV40 has been shown to form a complex with p53 and to inhibit p53-mediated transcription (55), the baseline mutation or inactivation of p53 in all three cell lines was null or very low, as detected by immunocytochemistry with the monoclonal antibody used. Treatment of cells with DMBA did not affect the baseline loss of fhit nor mutation or inactivation of p53. In addition, DMBA was able to stimulate apoptosis, again possibly involving oxidative stress-stimulated induction of apoptosis-related genes, an effect that was significantly less pronounced in M13SV1 than in the two tumorigenic cell lines. This finding indicates that the non-tumorigenic immortal cell line without further tumorigenic development has a different ability to respond to DMBA by triggering the apoptotic process. Previous in vitro studies had shown the ability of DMBA to induce apoptosis in cell lines derived from MCF-7 human breast epithelial cancer cells (56).

DMBA also induced the formation of bulky DNA adducts in the investigated human mammary cells, with patterns that were similar to those detected either following in vitro reaction of metabolically activated DMBA with calf thymus DNA (37) or in mouse cells (57) or in mammary epithelial cells of DMBA-treated rats $(37,58)$. The spots observed at ${ }^{32} \mathrm{P}$-postlabeling are likely to reflect reactions between either anti- or syn-DMBA-dihydrodiolepoxide and either $\mathrm{dG}$ or $\mathrm{dA}$ $(57,58)$. Interestingly, induction of DMBA-DNA adducts was significantly higher in M13SV1 cells than in the two tumorigenic cell lines. Likewise, a slight but significant DMBArelated increase of $8-\mathrm{OH}-\mathrm{dG}$, which had previously been observed in mammary glands of rats treated with DMBA (59), was only detectable in the immortalized but non-tumorigenic M13SV1 cells. Irrespective of the cell line, treatment with DMBA significantly enhanced the levels of common 4977-bp mtDNA deletion, an effect that had never been reported previously either in vitro or in vivo. This specific deletion is a marker of total mtDNA mutations and deletions, which increases during the progression of mitochondrial degeneration related to oxidative stress and to decline of oxidative phosphorylation $(60,61)$.

Treatment of cells with NAC alone did not affect any of the investigated end-points. Moreover, NAC did not attenuate induction by DMBA of apoptosis and of the common 4977-bp mtDNA deletion to a significant extent. No information is available regarding the influence of NAC on this specific mtDNA deletion, but we previously showed that oral NAC is quite effective in inhibiting the adducts to mtDNA in lung cells of cigarette smoke-exposed rats (62). A vast literature is available regarding modulation of apoptosis by NAC. In the large majority of 390 studies on this subject cited in Medline from January 1, 1989, to October 31, 2004, NAC inhibited apoptosis induced by either biological, physical or chemical agents in a variety of test systems (63). These data underlie the ability of NAC to protect the cells by inhibiting upstream mechanisms, such as DNA damage and oxidative stress-induced signalling, that trigger the apoptotic cascade. Interestingly, differential effects are reported in the literature depending on target cells. For instance, NAC enhanced the frequency of apoptosis in transformed cells but not in normal cells $(64,65)$.

NAC protected the cells from DMBA-induced toxicity and DNA alterations, in agreement with our previous in vivo studies, showing that administration of NAC with the diet resulted in a significant decrease of DNA adduct levels in both liver and mammary epithelial cells of Sprague-Dawley rats receiving a single dose of DMBA $(34,37)$. In the present study, NAC inhibited the loss of viability caused by DMBA in all three cell clones, and decreased the levels of bulky DNA adducts in DMBA-treated cells. The latter effect was particularly evident in the immortalized but non-tumorigenic M13SV1 cells, where the highest DNA adduct levels were induced by this carcinogenic PAH. In the same cells, DMBArelated oxidative DNA damage was no longer observed following co-treatment with NAC. In view of the stem cell hypothesis of carcinogenesis, M13SV1 cells provide good information in the assessment of chemopreventive effects (66).

Presumably, in M13SV1 cells there was a more efficient metabolic activation of DMBA and/or a lower detoxification of electrophilic derivatives and of reactive oxygen species, which was compensated by co-treating the cells with NAC. This thiol compound displays a remarkable array of mechanisms and protective effects towards DNA damage, oxidative stress-induced intracellular signalling and carcinogenesis, also including its ability to act as a nucleophile, which would explain inhibition of DMBA-induced bulky DNA adducts, and as a scavenger of reactive oxygen species, which would explain the lack of oxidative DNA damage observed in cells treated with DMBA (reviewed in refs. 33,34). It is also documented by many studies that NAC is capable of modulating a variety of signal transduction pathways altered by toxic agents, carcinogens, cytokines, and changes of the redox potential. These effects include, among others, decrease of c-fos and c-jun induction, inhibition of activation and binding activity of AP-1, and inhibition of activation and nuclear translocation 
of NF-кB (34). Modulation of these end-points by NAC was not investigated in the present study.

Non-tumorigenic but immortalized cells exhibit a differential response to DMBA. Since it has been shown that some phenotypic features of these cells closely resemble those of adult normal breast epithelial stem cells, the question arises of whether the normal breast epithelial stem cell behaves as the immortalized but non-tumorigenic cell. In conclusion, the immortal cell line derived from Type I HBECs without further tumorigenic progression (M13SV1) appears to be the most susceptible both to DMBA-related alterations and to the protective effects of NAC.

\section{Acknowledgements}

This work was supported by Associazione Italiana per la Ricerca sul Cancro (AIRC) to S.D.F., Fondazione CARIGE to A.D.F., and National Institute of Environmental Sciences (NIEHS) Superfund Basic Science Project [PA42 ES04911] to J.E.T.

\section{References}

1. Markert CL: Neoplasia: a disease of cell differentiation. Cancer Res 28: 1908-1914, 1968.

2. Pierce GB: Neoplasms, differentiation and mutations. Am J Pathol 77: 103-118, 1974.

3. Nowell PC: The clonal evolution of tumor cell populations. Science 194: 23-28, 1976.

4. Fialkow PJ: Clonal origin of human tumors. Annu Rev Med 30: 135-143, 1979.

5. Till JE: Stem cells in differentiation and neoplasm. J Cell Physiol (suppl 1): 3-11, 1982.

6. Greaves MF: Differentiation-linked leukemiogenesis in lymphocytes. Science 234: 697-704, 1986.

7. Spandidos DA: A unified theory for the development of cancer. Biosci Rep 6: 691-708, 1986.

8. Sell S: Cellular origin of cancer: dedifferentiation or stem cell maturation arrest? Environ Health Perspect 101: 15-26, 1993.

9. Sun W, Kang KS, Morita I, Trosko JE and Chang CC: High susceptibility of a human breast epithelial cell type with stem cell characteristics to telomerase activation and immortalization. Cancer Res 59: 6118-6123, 1999.

10. Chang CC, Trosko JE, El-Fouly MH, Gibson DR and D'Ambrosio SM: Contact insensitivity of a subpopulation of normal human fetal kidney epithelial cells and of human carcinoma cell lines. Cancer Res 47: 1643-1645, 1987.

11. Kao C-Y, Nomata K, Oakley CS, Welsch CW and Chang C-C: Two types of normal human breast epithelial cells derived from reduction mammoplasty: phenotypic characterization and response to SV40 transfection. Carcinogenesis 16: 531-538, 1995.

12. Toma JG, Akhavan M, Fernandes KJ, Barnabe-Heider F, Sadikot A, Kaplan DR and Miller FD: Isolation and of multipotent adult stem cells from the dermis of mammalian skin. Nat Cell Biol 3: 778-784, 2001.

13. Tai MH, Chang C-C, Kiupel M, Webster JD, Olson LK and Trosko JE: Oct4 expression in adult human stem cells: evidence in support of the stem cell theory of carcinogenesis. Carcinogenesis 26: 495-502, 2005.

14. Matic M, Petrov IN, Chen S, Wang C, Dimitrijevich SD and Wolosin JM: Stem cells of the corneal epithelium lack connexins and metabolite transfer capacity. Differentiation 61: 251-260, 1997.

15. Matic M, Evans WH, Brink PR and Simon M: Epidermal cells do not communicate through gap junctions. J Invest Dermatol 118: 110-116, 2002.

16. Tsai RYL and McKay RDG: A nucleolar mechanism controlling cell proliferation in stem cells and cancer cells. Genes Dev 16: 2991-3003, 2002.

17. Linning KD, Tai MH, Madhukar BV, Chang C-C, Reed DN, Ferber S, Trosko JE and Olson LK: Redox-mediated enrichment of self-renewing adult human pancreatic cells that possess endocrine differentiation potential. Pancreas 29: 64-76, 2004.
18. Lin TM, Tsai JL, Lin SD, Lai CS and Chang C-C: Redox state and calcium modulate proliferation and differentiation of human mesenchymal stem cells derived from adipose tissues. Stem Cell Dev 14: 92-102, 2005.

19. Pittenger MF, Mackay AM, Beck SC, Jaiswal RK, Douglas R, Mosca JD, Moorman MA, Simonetti DW, Craig S and Marshak DR: Multilineage potential of adult human mesenchymal stem cells. Science 284: 143-147, 1999.

20. Reyes M, Dudek A, Jahagirdar B, Koodie L, Marker PH and Verfaillie CM: Origin of endothelial progenitors in human postnatal bone marrow. J Clin Invest 109: 337-346, 2002.

21. Trosko JE, Chang C-C, Wilson MR, Upham B, Hayashi T and Wade M: Gap junctions and the regulation of cellular functions of stem cells during development and differentiation. Methods 20: 245-264, 2000.

22. Dick JE: Breast cancer stem cells revealed. Proc Natl Acad Sci USA 100: 3547-3549, 2003.

23. Singh SK, Hawkins C, Clarke ID, Squire JA, Bayani J, Hide T, Henkelman RM, Cusimano MD and Dirks PB: Identification of human brain tumor initiating cells. Nature 432: 143-147, 2004.

24. Cozzio A, Passegue E, Ayton PM, Karsunky H, Cleary ML and Weissman IL: Similar MLL-associated leukemias arising from self-renewing stem cells and short-lived myeloid progenitors. Genes Dev 17: 3029-3035, 2003.

25. Kondo T, Setoguchi T and Taga T: Persistence of a small subpopulation of cancer stem-like cells in the C6 glioma cell line. Proc Natl Acad Sci USA 101: 781-786, 2004.

26. Yuan X, Curtin J, Xiong Y, Liu G, Waschsmann-Hogiu S, Farkas DL, Black KL and Yu JS: Isolation of cancer stem cells from adult glioblastoma multiforme. Oncogene 23: 9392-9400, 2004.

27. Galli R, Binda E, Orfanelli U, Cipelletti B, Gritti A, De Vitis S, Fiocco R, Foroni C, Dimeco F and Vescovi A: Isolation and characterization of tumorigenic, stem-like neural precursors from human glioblastomas. Cancer Res 64: 7011-7021, 2004.

28. Ponti D, Costa A, Zaffaroni N, Pratesi G, Petrangolini G, Coradini D, Pilotti S, Pierotti MA and Daidone MG: Isolation and in vitro propagation of tumorigenic breast cancer cells with stem/progenitor cell properties. Cancer Res 65: 5506-5511, 2005.

29. Monk M and Holding C: Human embryonic genes re-expressed in cancer cells. Oncogene 20: 8085-8091, 2001

30. Chang C-C, Sun W, Cruz A, Saitoh M, Tai MH and Trosko JE: A human breast epithelial cell type with stem cell characteristics as target cells for carcinogenesis. Radiat Res 155: 201-207, 2001.

31. Park J-S, Ahn N-S, Yang S-R, Noh D-Y, Kim S-H, Ahn C, Kim J-Y, Kim S-H, Chang C-C, Trosko JE, Lee Y-S and Kang K-S: Identification of differentially expressed genes in human breast epithelial cells associated with stem cell properties and immortalization. Int J Oncol 24: 1545-1558, 2004.

32. Kang K-S, Sun W, Nomata K, Morita I, Cruz A, Liu C-J, Trosko JE and Chang C-C: Involvement of tyrosine phosphorylation of p185c-erbB2/neu in tumorigenicity induced by $\mathrm{X}$-rays and neu oncogene in human breast epithelial cells. Mol Carcinog 21: 225-233, 1998.

33. De Flora S, Izzotti A, D'Agostini F and Balansky RM: Mechanisms of $N$-acetylcysteine in the prevention of DNA damage and cancer, with special reference to smoking-related end-points. Carcinogenesis 22: 999-1013, 2001.

34. De Flora S, Izzotti A, Albini A, D'Agostini F, Bagnasco M and Balansky RM: Antigenotoxic and cancer preventive mechanisms of $N$-acetyl-L-cysteine. In: Cancer Chemoprevention, Vol. 1: Promising Cancer Chemopreventive Agents. Kelloff GJ, Hawk ET and Sigman CC (eds). The Humana Press Inc., Totowa, NJ, pp37-67, 2004.

35. Zhang SM, Willett WC, Selhub J, Manson JE, Colditz GA and Hankinson SE: A prospective study of total cysteine and risk of breast cancer. Cancer Epidemiol Biomarkers Prev 12: 1158-1193, 2003.

36. Pozzolini M, Scarfi S, Benatti U and Giovine M: Interference in MTT cell viability assay in activated macrophage cell line. Anal Biochem 313: 338-341, 2003.

37. Izzotti A, Camoirano A, Cartiglia C, Grubbs CJ, Lubet RA, Kelloff GJ and De Flora S: Patterns of DNA adduct formation in liver and mammary epithelial cells of rats treated with 7,12dimethylbenz $(a)$ anthracene, and selective effects of chemopreventive agents. Cancer Res 59: 4285-4290, 1999.

38. Izzotti A, Cartiglia $C$, Taningher M, De Flora $S$ and Balansky R: Age-related increases of 8-hydroxy-2'-deoxyguanosine and DNA protein crosslinks in mouse organs. Mutat Res 446: 215-223, 1999. 
39. Hamblet NS and Castora FJ: Mitochondrial DNA deletion analysis: a comparison of PCR quantitative methods. Biochem Biophys Res Commun 207: 839-847, 1995.

40. Kang KS, Morita I, Cruz A, Jeon YJ, Trosko JE and Chang C-C: Expression of estrogen receptors in a normal human breast epithelial cell type with luminal and stem cell characteristics and its neoplastically transformed cell lines. Carcinogenesis 18: 251-257, 1997.

41. Fujimoto N, Honda H and Kitamura S: Effects of environmental estrogenic chemicals on AP-1 mediated transcription with estrogen receptors alpha and beta. J Steroid Mol Biol 88: 53-59, 2004.

42. Bachmeier BE, Vene R, Iancu CM, Pfeffer U, Mayer B, Noonan D, Albini A, Jochum M and Nerlich AG: Transcriptional control of cell density dependent regulation of matrix metalloproteinase and TIMP expression in breast cancer cell lines. Thromb Haemost 93: 761-769, 2005.

43. Rahman KW and Sarkar FH: Inhibition of nuclear translocation of NF- $\mathrm{BB}$ contributes to 3,3'diindolylmethane-induced apoptosis in breast cancer cells. Cancer Res 65: 364-371, 2005.

44. Upham BL and Wagner JG: Toxicant-induced oxidative stress in cancer. Toxicol Sci 64: 1-3, 2001.

45. Angel P and Karin M: The role of Jun, Fos and the AP-1 complex in cell-proliferation and transformation. Biochim Biophys Acta 1072: 129-157, 1991 .

46. Li X, Eckard J, Shah R, Malluck C and Frenkel K: Interleukin-1 $\alpha$ up-regulation in vivo by a potent carcinogen 7,12-dimethylbenz $(a)$ anthracene (DMBA) and control of DMBA-induced inflammatory responses. Cancer Res 62: 417-423, 2002.

47. Oberley TD: Oxidative damage and cancer. Am J Pathol 160: 403-408, 2002.

48. Long DJ, Waikel RL, Wang X-J, Roop DR and Jaiswal AK: NAD(P)H: quinone oxide-reductase deficiency and increased susceptibility to 7,12-dimethylbenz $(a)$ anthracene-induced carcinogenesis in mouse skin. J Natl Cancer Inst 93: 1167-1170, 2001.

49. Yusuf R and Frenkel K: Oxidative stress-mediated transformation of MCF-10 human mammary cells: roles of hydrocortisone (HC), 17-beta-estradiol (E2), and 7,12-dimethylbenz $(a)$ anthracene (DMBA). Free Radic Biol Med 31: 427, 2001.

50. Tachikawa T, Kohno Y, Matsui Y and Yoshiki S: In vitro early changes in intercellular junctions by treatment with a chemical carcinogen. Carcinogenesis 7: 885-892, 1986.

51. D'Amico M, Hulit J, Amanatullah DF, Zafonte BT, Albanese C, Bouzahzah B, Fu M, Augenlicht LH, Donehover LA, Takemaru K, Moon RT, Davis R, Lisanti MP, Shtutman M, Zhurinnsky J, Benze'ev A, Troussard AA, Dedhar S and Pestell RG: The integrin-linked kinase regulates the cyclin D1 gene through glycogen synthase kinase 3 beta and cAMP-responsive elementbinding protein-dependent pathways. J Biol Chem 275: 32649-32657, 2000.

52. Subbaramaiah K, Norton L, Gerald W and Dannenberg AJ: Cox-2 is overexpressed in HER/neu-positive breast cancer: evidence for involvement of AP-1 and PEA3. J Biol Chem 277: 18649-18657, 2002.
53. Sato T, Akiyama F, Sakamoto G, Kasumi F and Nakayama Y: Accumulation of genetic alterations and progression of primary breast cancer. Cancer Res 52: 7737-7741, 1991.

54. Hu B, Han SY, Wang X, Ottey M, Potoczek MB, Dicker A, Huebner $\mathrm{K}$ and Wang $\mathrm{Y}$ : Involvement of the Fhit gene in the ionizing radiation-activated ATR/CHK1 pathway. J Cell Physiol 202: 518-523, 2005.

55. Dobbelstein M and Roth J: The large $\mathrm{T}$ antigen of simian virus 40 binds and inactivates p53 but not p73. J Gen Virol 79: 3079-3083, 1998.

56. Ciolino HP, Dankwah M and Yeh GC: Resistance of MCF-7 cells to dimethylbenz(a)anthracene-induced apoptosis is due to reduced CYP1A1 expression. Int J Oncol 21: 385-391, 2002.

57. Vericat JA, Cheng SC and Dipple A: Absolute stereochemistry of the major 7,12-dimethylbenz $(a)$ anthracene-DNA adducts formed in mouse cells. Carcinogenesis 10: 567-570, 1989.

58. Singletary KW, Parker HM and Milner JA: Identification and in vivo formation of ${ }^{32} \mathrm{P}$-postlabeled rat mammary DMBA-DNA adducts. Carcinogenesis 11: 1959-1963, 1990.

59. El-Bayoumy K, Chae YH, Rosa JG, Williams LK, Desai D, Amin S and Fiala E: The effects of 1-nitropyrene, 2-amino-1methyl-6-phenylimidazo[4,5-b]pyridine and 7,12-dimethylbenz $(a)$ anthracene on 8-hydroxy-2'-deoxyguanosine levels in the rat mammary gland and modulation by dietary 1,4phenylenebis(methylene) selenocyanate. Cancer Lett 151: 7-13, 2000 .

60. Cortopassi GA, Shibata G, Soong N-W and Arnheim N: A pattern of accumulation of a somatic deletion of mitochondrial DNA in aging human tissues. Proc Natl Acad Sci USA 89: 7370-7374, 1992.

61. Wallace DC: Mitochondrial genetics: a paradigm for aging and degenerative diseases? Science 256: 628-632, 1992.

62. Balansky R, Izzotti A, Scatolini L, D'Agostini F and De Flora S: Induction by carcinogens and chemoprevention by $N$-acetylcysteine of adducts to mitochondrial DNA in rat organs. Cancer Res 56: 1642-1647, 1996

63. D'Agostini F, Izzotti A, Balansky RM, Bennicelli C and De Flora S: Modulation of apoptosis by chemopreventive agents. Mutat Res 591: 173-186, 2005.

64. Liu M, Pelling JC, Ju J, Chu E and Brash DE: Antioxidant action via p53-mediated apoptosis. Cancer Res 58: 1723-1729, 1998.

65. Havre PA, O'Reilly S, McCormick JJ and Brash DE: Transformed and tumor-derived human cells exhibit preferential sensitivity to the thiol antioxidants, $N$-acetylcysteine and penicillamine. Cancer Res 62: 1143-1149, 2002.

66. Trosko JE, Chang C-C, Upham BL and Tai MH: The role of human adult stem cells and cell-cell communication in cancer chemoprevention and chemotherapy strategies. Mutat Res 591: 187-197, 2005. 